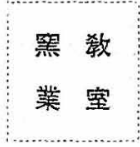

\section{II. 窯炉の解説（続）}

\section{（5）ロータリーキルンの焼成能力の検討}

前攱ではわが国のセメントキルンの焼成能力汇つい

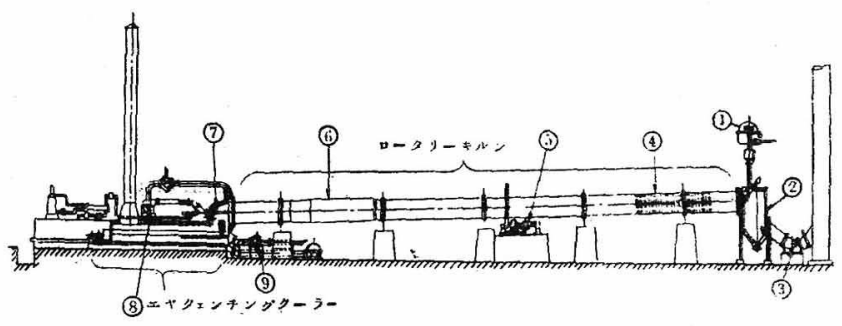
(1) Ferris ステリー供給機

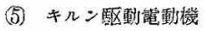
(9) 二次觉風機

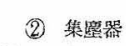

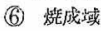

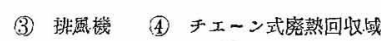
(7) 重油バーナー
(8)一次送栭機

第 20 図 アリスキャーマーズキルンの1例
炉

て述べたが，最近入手した資料》とよれば，アリスキャ ーマーズ社が保証する窯の能力は第 6 表の上5で， キ ルン No.1 10 怡前揭の Eckel の公式似 No.11 19 はアメりカセメント運合会 (A.P.C.A.) の公式烧 ぼ合致していることを知った。

No.20 27 以掋大部分の寸法が 不明なため計算することはできな いが，祘气らく A.P.C.A. 公式 が適合するのではないて教克ら れる。第 22〜23 図㹥, A社の保 証能力と筧の内容積呿よび内壁面

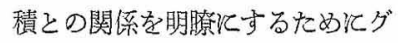
ラフ化したタのである。
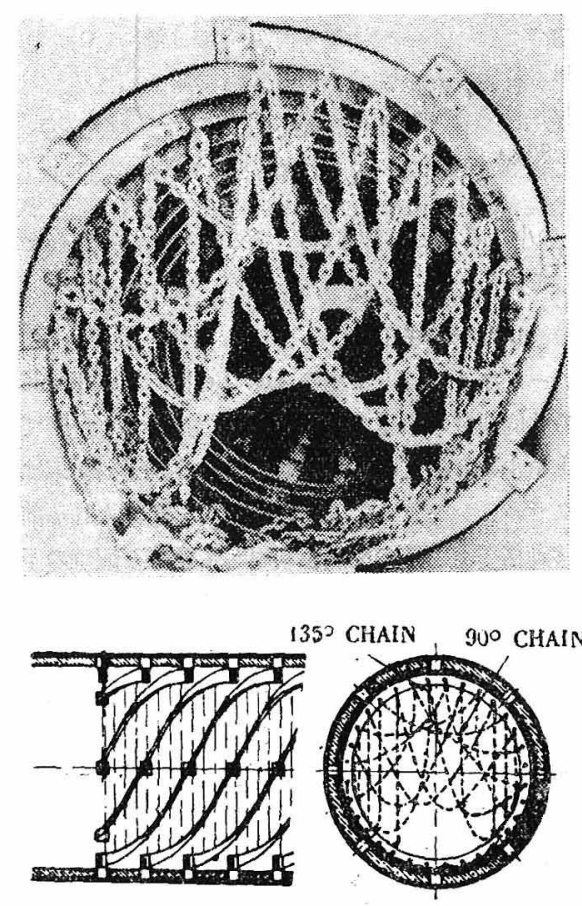

第 21 図同キルン奥部の熟回収用チェー ンカーテン

1)〔神戸製鋼】アリスチャーマーズ社のキルン

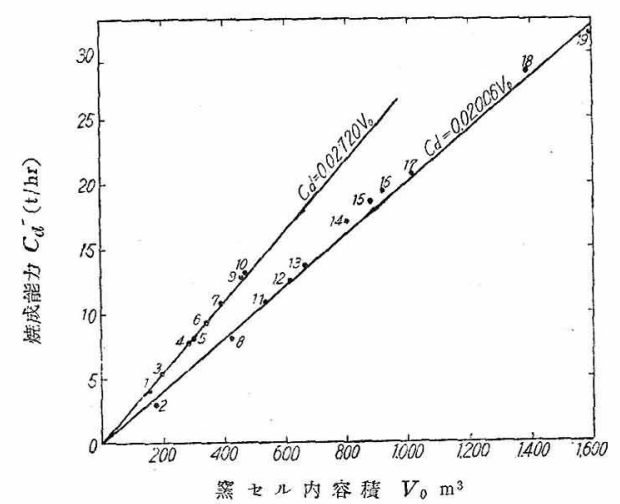

第 22 図 アリス・チャーマーズ製繁の燊成 能力と窑内容㣱 $\left(V_{0}\right)$

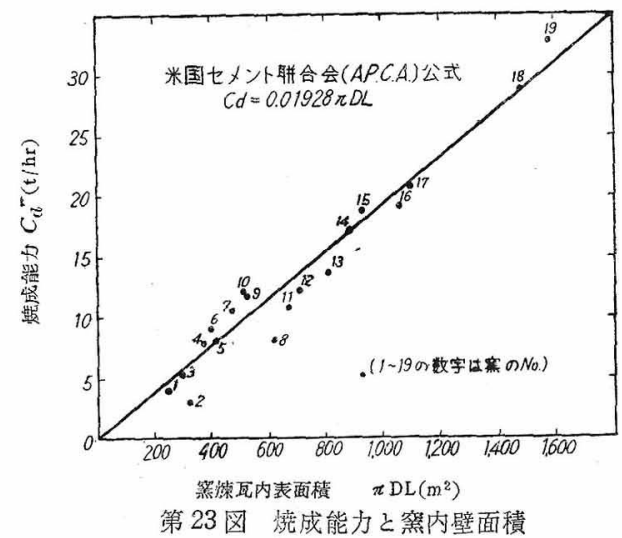


第6 表 アリスチャーマーズ社製キルンのサイズそ保証能力

\begin{tabular}{|c|c|c|c|c|c|c|c|}
\hline \multirow{2}{*}{$\begin{array}{c}\text { キルン } \\
\text { No. }\end{array}$} & \multirow{2}{*}{ 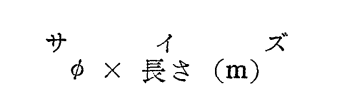 } & \multicolumn{2}{|c|}{ 保証能力（t/h） } & \multirow{2}{*}{ 湿/乾能力比 } & \multicolumn{2}{|c|}{ 乾式能力 $(t / h)$} & \multirow{2}{*}{ 曼適公式 } \\
\hline & & 畭 式 & 湿 式 & & \multicolumn{2}{|c|}{ (Eekel公式) (A.P.C.A.公式) } & \\
\hline 1 & $2.29 \times 38.1$ & 4.1 & 3.0 & 0.73 & 4.2 & 4.7 & \\
\hline 2 & $1.83 \times 67.0$ & 3.0 & 2.7 & 0.90 & 4.4 & 6.4 & \\
\hline 3 & $2.44 \times 42.7$ & 5.3 & 3.8 & 0.72 & 5.4 & 5.7 & \\
\hline 4 & $2.74 \times 48.8$ & 7.8 & 5.7 & 0.73 & 8.0 & 7.3 & \\
\hline 5 & $2.59 \times 56.4$ & 8.0 & 5.8 & $"$ & 8.2 & 8.0 & Eekel \\
\hline 6 & $3.05 \times 45.7$ & 9.2 & 6.7 & " & 9.5 & 7.7 & 公式 \\
\hline 7 & $3.05 \times 53.3$ & 10.6 & 7.8 & 0.74 & 11.1 & 9.0 & \\
\hline 8 & $2.44 \times 91.4$ & 8.1 & 7.1 & 0.88 & 11.6 & 12.1 & \\
\hline 9 & $3.20 \times 56.4$ & 12.8 & 9.2 & 0.92 & 13.0 & 10.1 & \\
\hline \multirow[t]{2}{*}{10} & $3.35 \times 53.3$ & 13.1 & 9.7 & 0.85 & 13.6 & 10.0 & \\
\hline & \multicolumn{6}{|c|}{ (以上平均 0.77 ) } & \\
\hline 11 & $2.90 \times 80.8$ & 10.7 & 9.2 & 0.86 & 15.0 & 12.9 & \\
\hline 12 & $3.20 \times 76.2$ & 12.4 & 10.8 & 0.87 & 17.5 & 13.6 & \\
\hline 13 & $3.05 \times 91.4$ & 13.5 & 11.7 & $"$ & 19.0 & 15.5 & \\
\hline 14 & $3.35 \times 91.4$ & 17.0 & 14.9 & 0.88 & 23.3 & 17.1 & \\
\hline 15 & $3.50 \times 91.4$ & 18.5 & 16.0 & 0.86 & 25.5 & 18.0 & \\
\hline 16 & $3.20 \times 114.3$ & 19.2 & 17.0 & 0.89 & 26.3 & 20.4 & A \\
\hline 17 & $3.43 \times 109.7$ & 20.6 & 17.7 & 0.86 & 29.4 & 21.1 & $\dot{\mathrm{P}}$ \\
\hline 18 & $3.50 \times 144.8$ & 28.4 & 24.8 & 0.87 & 40.5 & 28.5 & \\
\hline 19 & $3.66 \times 152.4$ & 32.6 & 28.4 & $"$ & 44.2 & 30.5 & $\mathrm{C}$ \\
\hline 20 & $2.29 \times 3.05 \times 2.59 \times 91.4$ & 8.3 & 7.2 & " & - & - & $\dot{\mathrm{A}}$ \\
\hline 21 & $2.59 \times 3.05 \times 2.59 \times 91.4$ & 10.0 & 8.5 & 0.85 & - & - & \\
\hline 22 & $2.44 \times 3.05 \times 91.4$ & 10.2 & 8.7 & $"$ & - & 一 & It \\
\hline 23 & $2.90 \times 3.35 \times 2.90 \times 91.4$ & 12.8 & 11.0 & 0.86 & - & - & \\
\hline 24 & $2.29 \times 2.59 \times 97.5$ & 8.3 & 7.2 & 0.87 & - & - & \\
\hline 25 & $3.05 \times 3.35 \times 53.3$ & 11.7 & 8.5 & 0.73 & - & - & \\
\hline 26 & $2.74 \times 3.20 \times 2.74 \times 99.1$ & 12.0 & 10.6 & 0.88 & - & - & \\
\hline 27 & $2.90 \times 3.35 \times 2.90 \times 114.3$ & 14.3 & 12.8 & 0.90 & - & - & \\
\hline
\end{tabular}

(以上平均 0.86)

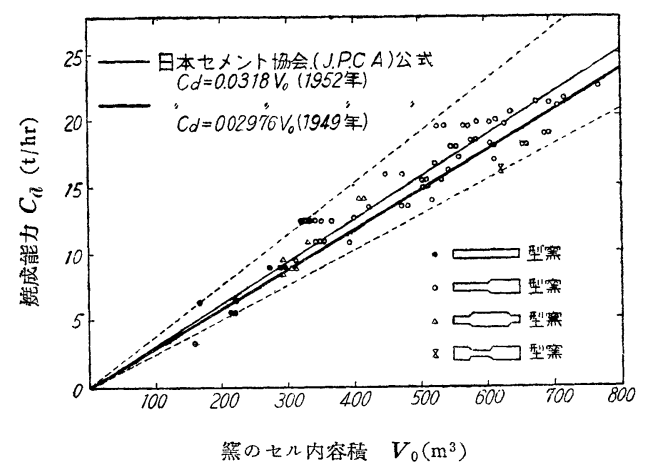

第 24 図焙成能力と窟のセル内容積 (形状別)

（日本乾式セメントキルン68基飞取材）

第 24 四は日本で現在稼働している 68 基の筀につ きそのセル内容積と焼成能力との関係の戦後の推移 を示したもので，ここ数年間に打ける鉒の比焼成能力 の增進は, 戦後わが国のセメント工場が次第整備さ れて来たことを物語るものである。

以上のグラフ飞見られるよ5亿筀の内容積の大きな ものは, 小さいるの比して比焼成能力 $\left(\mathrm{kg} . \mathrm{Cl}^{\prime} / \mathrm{m}^{3}\right.$
Vol）の小なることが知られ，ここでも筆者の持論を 襄書している。

\section{(6) レポールキルン}

レポールキルンはドイッの Dr. Lellep と Polisius 社との共同研究の所産で, その頭交字を取合せて Lepol キルンと名付けられたものである。原料粉末は 予めグラニュレーターで成粒し，それを䇺に入れる前 飞, 移動格子上で黨の廃熱を利用して乾燥と报焼の子 備的熱処理を行って篣にチャージするという点で劃期 的の発明と称すべきであろう。

これがため䇪の本体の長さは 25 30 $\mathrm{m}$ 程度のるの でも充分クリンカーが焼け，熱効率は非常飞良くて， 㖶突へ逃げる廃ガスの温度は最低 $70^{\circ} \mathrm{C}$ 位にもなり， セメント $1 \mathrm{t}$ 当りの所要熱量はわずか似 100 万 $\mathrm{kcal}$ 程度である。また, 筧の廃ガスは一度乃至二度ロスト ル上の原料層で濾過されるから, ダストのロスも比較 的少ない。

レポールキルンは買電の可能なところでは, 発電設 備の負担が免除されるから建設費が非常飞安くあが る。このため, 大戦に疲れたヨーロッパの大陸諸国で 
は再びレポールキルンが擡頭し, イタリーでは 1 基で 日産 $700 \mathrm{t}$ とる物よぶものがあるという。

ちなみに，レポールキルンは 全世界飞 440４50 基あるとき くが，そのうち日本では $2.6 \times$ $26 \mathrm{~m}$ と $2.8 \times 28 \mathrm{~m}$ のもの゙合 計 3 基位しかない。こんど䑾城 社の浜松工場飞入るものは 3.6 $\times 50 \mathrm{~m}$ ，日産約 $480 \mathrm{t}$ 位のもの ときいているが，その成績が一 般から大い注目されている。第25図は最新式のレ ポールキルン゙をを示す。

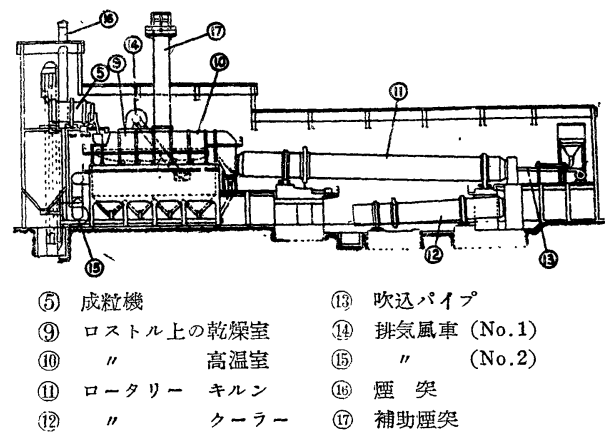

第 25 図最新式レポールキルン

\section{（7） 新しいシャフトキルン}

以上，セメント焼成の本命はロータリーキルンとの. 考觉のもと飞, 一応の解説を進めて来たが, 最近セメ ント界飞新しいダークホースすなわち最新式シャフ トキルンが出現し，ヨーロッパでは次第棌用され， 燃料費が少なくて，しかも建設費が非常に安いという ので注目をひいている。次に，これて関して昨年親し くこれを視察されたセメント技術協会小楖博士の報告 の一部を引用して参考澬したい。

シャフトキルンの熱経済なととは，既に古くから一 般に認められていたが，この種の案の欠陷は製品の品 質がもらで，ロータリーキルンの製品に比して品質の 劣ること，大量生産の困難な点等にあった。

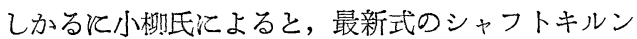
は半自動式で，炉況が非常飞安定し，したがって製品 の品質す一定して良いので，ドイッでは現とキュール 博士の長男がシャフトキルンで高級セメントを焼いて いる。また，そのシャフトキルン工場の建設費は，同 じ能力のロータリーキルン工場の約 $1 / 2 \sim 2 / 3$ ですむと いうところと魅力があり，現にイギリス，スイス，才 一スタリー，スカンジナビヤ諸国では盛ん新設され つつあるという。

2) Rock Products, 56 [9] 81 (1953)

3）小柳勝義, セメントコンクリート, No.802023 (1953)
次に新旧シャフトキルンの比較とその変䆃について のベる。

第 7 表 年代によるシャフトキルンの変遷

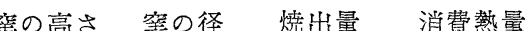

$(\mathrm{m}) \quad(\mathrm{m}) \quad \mathrm{t} / \mathrm{d} \quad \mathrm{kcal} / \mathrm{kg} \cdot \mathrm{Cl}$

ドラフト

$\begin{array}{lllll}8 \sim 9 & 2 & \sim 2.2 & 20 & 1200 \sim 1000\end{array}$

自然通風

$8 \sim 9$

$2.5 \sim 2.6$

$35 \sim 55$

$1600 \sim 1400$

ターボファン

$10 \sim 14$

$9 \sim 12$

$8 \sim 9$

$2.7 \sim 2.9 \quad 80 \sim 100 \quad 1400 \sim 1200$

$2.6 \sim 2.8 \quad 100 \sim 150 \quad 1300 \sim 1100$ 強制通風

$2.4 \sim 2.5 \quad 150 \sim 180 \quad 1100 \sim 1000$

$<2.3 \quad 180 \sim 220 \quad 1000 \sim 900$

第 8 表 シャフトキルンの操業状態の推移

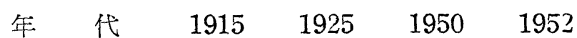

1 in $\mathrm{m}$

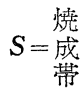
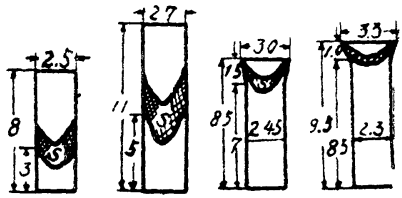

焼出乙量 $\mathrm{t} / \mathrm{day}$

35-55 $\quad 70-90 \quad 165-190$

220

然料消費

$\mathrm{kcal} / \mathrm{kg}$

$1600-1300-1100-$

$\begin{array}{lrr}1400 & 1200 & 1000\end{array}$

900

燃焼空気

$\mathrm{m}^{3} / \mathrm{min}$

空気压力

$\mathrm{mm}$ 水柱

50-65 80-100 140-150

165

廃気温度

$100-300 \quad 500-700 \quad 1400$

1600

クリンカー

$\begin{array}{lllll}\text { クリンカー } & 450 & 400 & 275 & 250\end{array}$

$500 \quad 400 \quad 300$

275

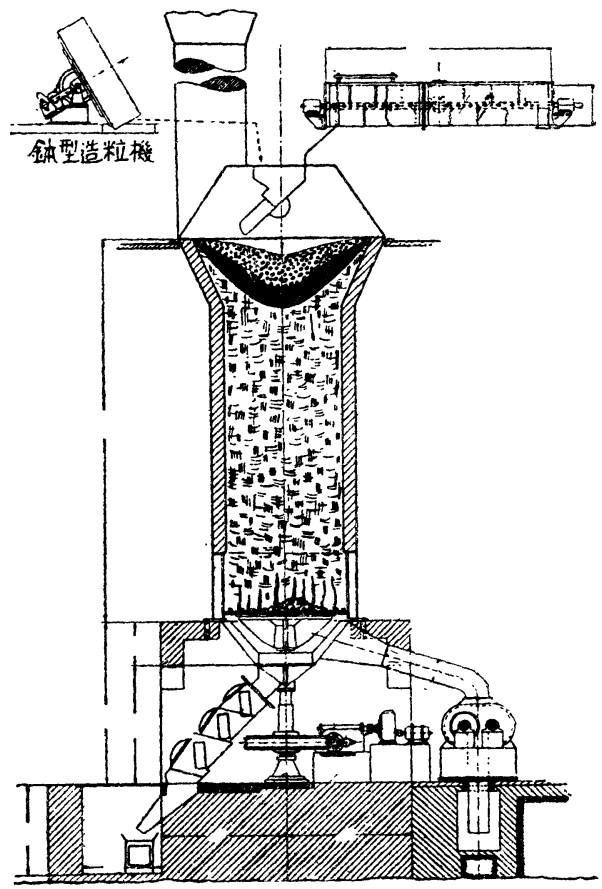

第 26 図 最新式のシャフトキルン 
以上を綜合すれば次の通り。

a）シャフトキルンの墨 1 基としての能力は年代と 共増加して来た。

b）焼成带は昔は厚くて下方にあったが，年代と共 飞層は薄く上部淫って来て, 迅速焼成, 迅速冷 却が行われるようとなり，セメントの品質るよく なって来た。

c）燃料此消費量忹年代と共飞漸減して来た。

d）燃焼用空気量と圧力は著しく増加し, 完全燃焼 を期している。

e）廃ガスとクリンカー温度は漸減し，ヒートバラ ンスは改善されて来た。

f）チャージする原料は音は䗲瓦形でやったが，最 近は $5 \mathrm{~mm} \phi$ のボールレしているため熱処理が容

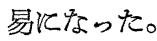

g）化学的には S.M. を上げ，末た焼成を容易飞 するため, 現在原料汇対して $1 \%$ 程度の螢石を 添加している。

以上種々改善の結果，少ない燃料費で良質のセメン トができるようとなった。

（8）ロータリーキルンと最新式シャフトキルンと の建設費の比較

今日セメント工場の経済単位浑，大体每時 $20 \mathrm{t}$ の 羔 2 基と考光られている。これ陻する資金は，時と 場所やそれぞれの条件によって区々であるが，大体ア メリカでは，原石と粘土山を除き工場の建設費だけで 約 600 万ドル，すなわち邦貨換算約 20 億円とい5巨 費を要する。現在わが国では附属設備等を全部入れて 完譬なセメント工場を造るとすれば,年産セメント $1 \mathrm{t}$ 当り約 1 万円と考壳られている。この建設費の高いこ そが今日のセメント業界若返りに対する悩みであると 同時に,新工場建設に対するブレーキともなっている。

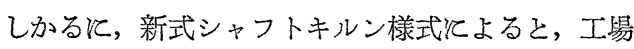
の建設費はロータリーキルン樣式汇よる場合の 50〜 60\%ですむていうから耳よりな話である。

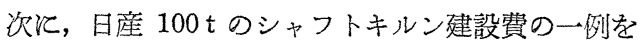

示す。ただし，箪以外はロータリーキルンの場合もシ ャフトキルンの場合も大体同㥞であるから，単飞筣の 建設費のみを比較して全班を推すわけとは行かないこ とを断って招く。

第 9 表 180 220t/day のシャフトキルンの建設 費 $(1950$ 年価格)

費目費目 (円) 参考費目 (円)

調合原料とコークス秤量機 12,400

同上コンベャー

- 94,600

鋪形グラニュレーター

81,700

回転グラニュレーター

混合用スネッキ

湿形原料圧縮械

-

301,000

51,600

- $\quad 129,000$

排気ファン，フリュー

和よび緟突

筀のシェルと内張金物

窯上カバーと原料送达機

51,600

クリンカー取出し装置

回転ロストル1式

水圧式空気遮断装置

ルーツブローワー（フィル

夕一付)

エレベーター,コンベャー,

床扮よび階段等

モータ一，配電板招よびそ の据付

172,000

86,000

$103,200 \bigcirc 946,000$

344,000

240,800

206,400

258,000

344,000

煉瓦張 $\left(11 \mathrm{~m}^{3}=26 \times 650 \mathrm{t}\right)$

146,200

基礎工事と土工費

60,200

機械据付

その他（各種メーター等を 含む)

120,400

120,400

合計

$2,506,900$

しかし，このような安価な證が生れて来ると、ロ一 タリーキルンの牙城をゆすぶることとなるが，ロータ

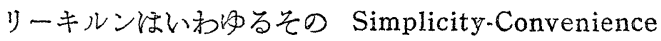
-Safety-Efficiency そいら点から，そう䉍単汇その牙 城をシャフトキルンと明社渡するのと考光られない

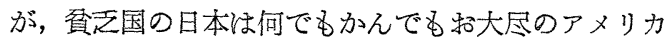
の真似をするのは荐觉物で，このシャフトキルンなぞ は一応真劍江祫討乙て見る必要はある，と等者情考兄 る。

(続く)

$$
\text { 鈴木巳代三著熹炉第 } 1 \text { 編 }
$$$$
\text { いよいよ発売。 }
$$

B 5 判, 本文 8 P 組 97 頁, 129 四 58 表, 䒺引付 定価 250 円 送料 20 円

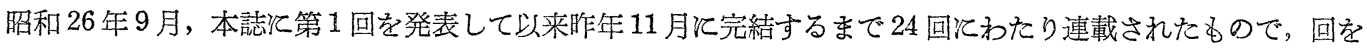
重ねるごとに全会員注視のうちと多大の好評を博し，完結 1 年前より本書つ刊行を問い合せるすのが多かった。 期待飞背かない好著であり，窯業技術者必携の書として購読を招すすめいたします。会員に限り 1 部 220 円

野口長次著

溫度の測定方法と計器の使い方

菜木洋一著
本交 $8 \mathrm{P}$ 組 55 頁 71 固 18 表 定価 120 丹送料 10 円

$$
\text { 泥しようと鋳込み定価 50 月 䢪料 } 10 \text { 円 } \mathrm{A} 5 \text { 判 }
$$

